\title{
Meningkatkan Hasil Belajar IPS dengan Model Pembelajaran Talking Stick pada Siswa Kelas IV MI Nurul Huda 1 Curug
}

Helma Nadyah Harahap

FAI Universita Ibn Khaldun Bogor

helmanadyah2094@gmail.com

Oking Setia Priatna

FAI Universitas Ibn Khaldun Bogor ospriatna075@gmail.com

\section{Kholil Nawawi}

FAI Universitas Ibn Khaldun Bogor kholiluika3@gmail.com

\begin{abstract}
Abstrak
Penelitian ini bertujuan untuk meningkatkan hasil belajar IPS di kelas IV MI Nurul Huda 1 Curug dengan menggunakan model pembelajaran talking stick. Metode yang digunakan adalah penelitian tindakan kelas yang dilaksanakan dengan tiga siklus, setiap siklus melalui tahap perencanaan, pelaksanaan, pengamatan dan refleksi. Intrumen yang digunakan yaitu tes dan lembar observasi. Teknik pengumpulan data terdiri dari observasi dan tes. Teknik analisis, data tes dengan menggunakan rumus rata-rata nilai dan data observasi dianalisis dengan menggunakan rumus persentase. Hasil penelitian menunjukkan bahwa nilai ratarata hasil belajar siswa pada siklus I belum cukup baik yaitu 68,55 dan persentase aktivitas guru $63,46 \%$ serta persentase aktivitas siswa $60 \%$. Pada siklus II mengalami perbaikan yang baik dengan nilai rata-rata hasil belajar 73 dan persentase aktivitas guru $73,07 \%$ serta persentase aktivitas siswa $70 \%$. Pada siklus III mengalami peningkatan sangat baik memperoleh nilai rata-rata hasil belajar 85,4 dan persentase aktivitas guru $82,69 \%$ serta persentase aktivitas siswa $82,5 \%$. Berdasarkan hasil penelitian, dapat disimpulkan bahwa Model Pembelajaran Talking Stick dapat meningkatkan hasil belajar IPS di kelas IV MI Nurul Huda 1 Curug.
\end{abstract}

Kata Kunci: Hasil Belajar, Ilmu Pengetahuan Sosial (IPS), Model Pembelajaran Talking Stick 


\begin{abstract}
This study aims to improve social studies learning outcomes in class IV MI Nurul Huda Curug by using the talking stick learning model. The method used is classroom action research conducted with three cycles, each cycle through planning, implementing, observing and reflecting. The instruments used were tests and observation sheets. Data collection techniques consist of observation and tests. Analysis techniques, test data using the formula of average values and observation data were analyzed using a percentage formula. The results of the study prove that the average value of student learning outcomes in cycle one is not good enough at 68.55 and the percentage of teacher activity is $63.46 \%$ and the percentage of student activity is $60 \%$. In the second cycle, there was a good increase with the average value of learning outcomes 73 and the percentage of teacher activity $73.07 \%$ and the percentage of student activity $70 \%$. In the third cycle, there was a very good increase with an average value of 85.4 learning outcomes and the percentage of teacher activity $82.69 \%$ and the percentage of student activity $82.5 \%$. Based on the results of the study, it can be concluded that the Talking Stick Learning Model can improve social studies learning outcomes in class IV MI Nurul Huda 1 Curug.
\end{abstract}

Keywords: Learning Outcomes, Social Sciences, Talking Stick Learning Model

\title{
Pendahuluan
}

Pendidikan merupakan salah satu bagian terpenting dalam kehidupan, karena tanpa adanya pendidikan seseorang tidak dapat menunjang kehidupannya kelak, baik dalam ekonomi dan status sosial. Dan pendidikan dianggap pula sebagai wadah untuk pengembangan potensi siswa, sehingga siswa mampu menghadapi dan menyelesaikan masalah kehidupan yang dihadapinya. Serta pendidikan secara istilah merupakan proses pengubahan sikap dan tingkah laku seseorang menjadi dewasa melalui upaya pengajaran dan pelatihan (Syah, 2014:10). Maka itu pendidikan sebagai tempat pertama untuk terbentuknya sikap, perilaku dan keterampilan seseorang.

Untuk meningkatkan mutu pendidikan maka perlu diiringi proses pembelajaran yang berkualitas serta hasil belajar untuk mengukur keberhasilan belajar yang meningkat. Menurut Nawawi dalam Susanto (2014:5) yang menyatakan bahwa hasil belajar ialah tingkat keberhasilan siswa dalam mempelajari materi yang dinyatakan dalam skor yang diperoleh dari hasil tes. Hasil belajar ini sangat mempengaruhi terhadap peningkatan mutu pendidikan, jika hasil belajar rendah maka hal tersebut akan memberikan pengaruh yang besar terhadap pendidikan. Faktor yang mempengaruhi hasil belajar yaitu dibagi menjadi dua ada faktor internal dan eksternal. Faktor internal faktor yang bersumber dari diri peserta didik seperti, minat, motovasi belajar, sikap, ketekunan, dan kesehatan peserta didik. Sedangkan faktor ekternal faktor yang bersumber dari luar diri peserta didik, seperti keluarga, lingkungan dan sekolah. Faktor yang sangat penting yang dapat mempengaruhi hasil belajar ialah faktor dari diri peserta didik itu sendiri, karena peserta didik subjek utama dalam proses pembalajaran. 
Pembelajaran Ilmu Pengetahuan Sosial (IPS) memberikan pembentukan manusia yang unggul karena kriteria manusia yang unggul yang memiliki pengetahuan yang luas, sikap dan nilai yang baik serta keterampilan memecahkan masalah. Sehingga Pembelajaran IPS perlu di berikan kepada siswa jenjang pendidikan dasar karena bukan hanya memberikan bekal pengetahuan saja, tetapi memberikan bekal nilai sikap serta keterampilan dalam bermasyarakat. Sesuai dengan tujuan pembelajaran IPS menurut Trianto (2013:174) adalah pelajaran yang mendidik peserta didik dan dapat memberi bekal kemampuan dasar kepada siswa untuk menegmbangkan diri sesuai dengan bakat, minat, kemampuan, dan lingkungannya, serta berbagai bekal siswa untuk melanjutkan pendidikan ke jenjang yang lebih tinggi.

Keberhasilan pembelajaran IPS sangat berpengaruh terhadap peranan guru, dimana peran guru hanya sebagai fasilitator saja, siswa yang berpastisipasi aktif dalam proses pembelajaran. Akan tetapi pembelajaran IPS dikenal dengan pembalajaran yang penuh dengan konsep atau teori-teori, sehingga membuat para peserta didik tidak tertarik terhadap pembelajaran IPS. Dapat dilihat sebagian besar pola pembelajaran IPS masih menggunakan metode yang konvensional dimana guru sebagai pusat pembelajaran, yang hanya menjelaskan konsep-konsep seputar IPS saja, tanpa ada interaksi yang aktif antara siswa dan guru, sehingga siswa pasif dalam pembelajaran Akhirnya siswa dalam proses pembelajaran sibuk bermainmain, kurang fokus dan konsentrasi terhadap materi pelajaran yang disampaikan guru. Sehingga tidak ada rasa antusias belajar dan membuat tidak adanya ketertarikan terhadap pembelajaran tersebut yang akan membuat tujuan pembelajaran tidak tercapai. Maka itu akabitnya berdampak pada rendahnya hasil belajar siswa dalam pembelajaran IPS.

Berdasarkan hasil pengamatan, sebagian siswa masih memperoleh nilai rendah pada mata pelajaran IPS. Hal ini dapat dilihat dari hasil ujian UAS (Ujian Akhir Semester) Semester 1 yang dihasilkan tidak sesuai dengan kriteria ketuntasan belajar siswa. Dimana hasil ujian semester yang diperoleh siswa kelas IV MI Nurul Huda 1 Curug pada mata pelajaran IPS masih di bawah Kriteria Ketuntasan Minimal belajar yaitu di bawah nilai 67 . Dari jumlah 20 siswa hanya 10 siswa yang memperoleh hasil belajar tinggi, dan 10 siswa memperoleh hasil belajar rendah. Dengan demikian dapat dikatakan bahwa hasil belajar siswa pada pembelajaran IPS masih rendah.

Di MI Nurul Huda 1 Curug dalam pembelajaran IPS kelas IV. Proses pembelajaran yang berlangsung guru hanya menggunakan metode yang konvensional (ceramah) hanya menerangkan saja tanpa adanya media pembelajaran setelah meyampaikan pesan guru langsung memberikan tugas yang harus dikerjakan di buku tematik yang terkait dengan pelajaran IPS, serta tidak melibatkan keaktifan siswa didalamnya, dan pembelajaran yang berpusat pada guru (teacher centered) sehingga membuat susana pembelajaran kurang menyenangkan, siswa menjadi jenuh dan kurang termotivasi dalam belajar. selain itu guru juga kurang menggunakan metode atau model pembelajaran yang bervariasi dan inovatif dalam pembelajaran sehingga membuat siswa pasif (diam) dan hal ini membuat siswa mudah bosan dan tidak konsentrasi terhadap materi pembelajaran IPS yang berlangsung. Penggunaan sarana prasana yang kurang memadai dalam proses pembelajaran yang dapat menyebabkan rendahnya hasil belajar siswa. Dalam hal semua ini akan 
menimbulkan sikap malas dalam belajar, kurang bersemangat, dan tidak tertarik dalam pembelajaran IPS, hal ini akan mempengaruhi hasil belajar siswa.

Untuk mengatasi permasalah-permasalah tersebut, hal yang harus diperhatikan yaitu peran guru dimana peran dalam penggunaan model pembelajaran yang mempengaruhi motivasi belajar dan semangat/antusias belajar. maka itu peneliti merencanakan usaha untuk meningkatkan hasil belajar dengan menggunakan model pembelajaran Talking Stick, karena dapat memacu agar peserta didik lebih giat dalam belajar seperti yang di kemukakan oleh, Muawanah (dalam Nikmatul Husnah, dkk : 2016) model talking stick dapat menciptakan suasana menyenangkan pada saat kegiatan pembelajaran berlangsung. Siswa dapat bermain dan bernyanyi bersama tanpa meninggalkan inti dari kegiatan pembelajaran itu sendiri. Selain itu, siswa akan lebih aktif karena memiliki hak untuk mengungkapan pendapat atau menjawab pertanyaan dari guru.

Talking stick ini juga pernah dibuktikan oleh Dwi Sari Rahmawati yang berjudul peningkatan kerjasama dan hasil belajar IPS melalui model talking stick pada siswa kelas V SD Negri 3 Barenglor Klaten Utara tahun ajaran 2013/2014. Dengan hasil penelitiannya diketahui bahwa pada pra siklus rata-rata nilai 71,5 , kemudian setelah diadakanna tindakan siklus I rata-rata nilai meningkat menjadi 76,5 dan tindakan siklus II rata-rata nilai meningkat menjadi 83,5.

Model pembelajaran talking stick mempunyai beberapa kelebihan, yaitu Menurut Shoimin (2014:199) antara lain (1) menguji kesiapan peserta didik dalam pembelajaran, (2) melatih peserta didik memahami materi dengan cepat, (3) Memacu agar peserta didik lebih giat belajar (belajar dahulu sebelum pelajaran dimulai), (4) Peserta didik berani mengemukakan pendapat. Selanjutnya Menurut Kurniasih dan Sani (2016:83) kelebihan model pembelajaran talking stick antara lain adalah (1) menguji kesiapan siswa dalam penguasaan materi pelajaran, (2) membaca dan memahami dengan cepat materi yang telah disampaikan, (3) agar lebih giat belajar karena siswa tidak pernah tau tongkat akan sampai pada gilirannya.

Langkah-langkah model pembelajaran talking stick pertama-tama guru menyampaikan materi pokok yang akan dipelajari, kemudian memberikan kesempatan kepada siswa untuk membaca dan mempelajari materi pada pegangannya/paketnya. Setelah selesai membaca buku dan mempelajarinya mempersiapkan siswa untuk menutup bukunya. Guru mengambil tongkat dan memberikan kepada siswa, setalah itu guru memberikan pertanyaan dan siswa yang memegang tongkat tersebut harus menjawabnya, demikian seterusnya sampai sebagian besar siswa mendapat bagian untuk menjawab setiap pertanyaan dari guru. Guru memberikan kesimpulan dan evaluasi (Aqib, 2016:26).

Berdasarkan uraian di atas, maka permasalahan penelitian ini adalah Apakah Penerapan Model Pembelajaran Talking Stick dapat meningkatkan hasil belajar IPS siswa kelas IV MI Nurul Huda 1 Curug?

Peneliti berharap dengan diterapkannya model pembelajaran talking stick dapat meningkatkan hasil belajar IPS siswa kelas IV MI Nurul Huda 1 Curug.

Snelbeker dalam Rusmono (dalam Rendi Lilit Iman P : 2017) hasil belajar adalah perubahan atau kemampuan baru yang diperoleh siswa setelah melakukan perbuatan belajar. Hasil belajar peserta didik dapat dilihat melalui nilai yang diperoleh peserta didik, jika nilai hasil belajar peserta didik masih di bawah standar Kriteria Ketuntasan Minimal (KKM) yang telah ditetapkan, maka dapat dikatakan 
bahwa hasil belajar peserta didik rendah dan suatu proses pembelajaran belum dapat dikatakan berhasil, dan sebaliknya.

\section{Metode}

Jenis penelitian yang dilakukan menggunakan Penelitian Tindakan Kelas (PTK). Menurut Arikunto dalam Suyadi (2015:18) mengemukakan bahwa Penelitian Tindakan Kelas (PTK) adalah pencermatan dalam bentuk tindakan terhadap kegiatan belajar yang sengaja dimunculkan dan terjadi dalam sebuah kelas secara bersamaan. Sedangkan menurut Tampubolon (2014:19) mengemukakan bahwa Penelitian Tindakan Kelas adalah penelitian yang dilakukan oleh pendidik di dalam kelasnya sendiri melalui refleksi diri.

Dari beberapa pengertian tersebut dapat ditarik kesimpulan bahwa Penelitian Tindakan Kelas merupakan penelitian yang dilakukan dalam kelas untuk meningkatkan kualitas belajar dan memecahkan masalah yang dialami pendidik maupun peserta didik. Mulyasa (2012:10) penelitian tindakan kelas (classroom action research) dengan tujuan untuk memperbaiki kualitas proses dan hasil belajar sekelompok peserta didik.

Penelitian ini dilaksanakan di MI Nurul Huda 1 Curug, subjek dari penelitian ini adalah seluruh siswa kelas IV yang berjumlah 10 orang terdiri dari 11 orang lakilaki dan 9 orang perempuan. Pelaksanaan penelitian ini dilaksanakan pada bulan Maret tahun 2019.

Instrumen yang digunakan lembar observasi aktivitas guru dan aktivitas siswa pada saat pembelajaran berlangsung pada mata pelajaran Ilmu Pengetahuan Sosial (IPS) dengan menggunakan model pembelajaran talking stick. Melalui pengamatan ini akan diketahui sikap dan perilaku siswa dan guru pada saat pembelajaran. Dan instrumen tes berupa soal piliha ganda yang dikerjakan pada akhir pembelajaran sebagai bahan evaluasi pada siklus berikutnya. Tes ini juga di gunakan sebagai alat ukur untuk menentukan keberhasilan hasil belajar siswa kelas IV pada mata pelajaran IPS. Teknik pengumpulan data dalam penelitian ini yaitu observasi aktivitas guru dan siswa dan tes. Analisis data dengan menganalisis tes hasil belajar siswa dengan menggunakan rata-rata nilai hasil belajar dan menganalisis data aktivitas guru dan siswa selama proses pembelajaran dengan menggunakan rumus sebagai berikut:

(1) Untuk menganalisis tes hasil belajar siswa pada pra siklus, siklus 1, siklus 2, dan siklus 3 menggunakan nilai rata-rata.

$$
\begin{aligned}
& \text { Sudijono } \quad(2017: 81) \quad \text { dengan rumus yang di gunakan yaitu: } \\
& \text { Nilai Rata-rata }=\frac{\text { Jumlah nilai seluruh siswa }}{\text { Jumlah siswa }}
\end{aligned}
$$

(2) Untuk menganalisis data aktivitas guru dan siswa yang diamati oleh observer menggunakan teknik persentase (\%).

$$
\begin{aligned}
& \text { Sudijono } \quad(2017: 43) \text { dengan rumus yang di gunakan yaitu: } \\
& \text { Persentase }=\frac{\text { Skor yang diperoleh }}{\text { Jumlah skor maksimum }} \times 100 \%
\end{aligned}
$$

Dalam penelitian ini terdapat empat tahapan yang harus dilalui, yaitu (1) Perencanaan, (2) pelaksanaan, (3) pengamatan, dan (4) refleksi (Arikunto, dkk, 2012:16) 


\section{Siklus I}

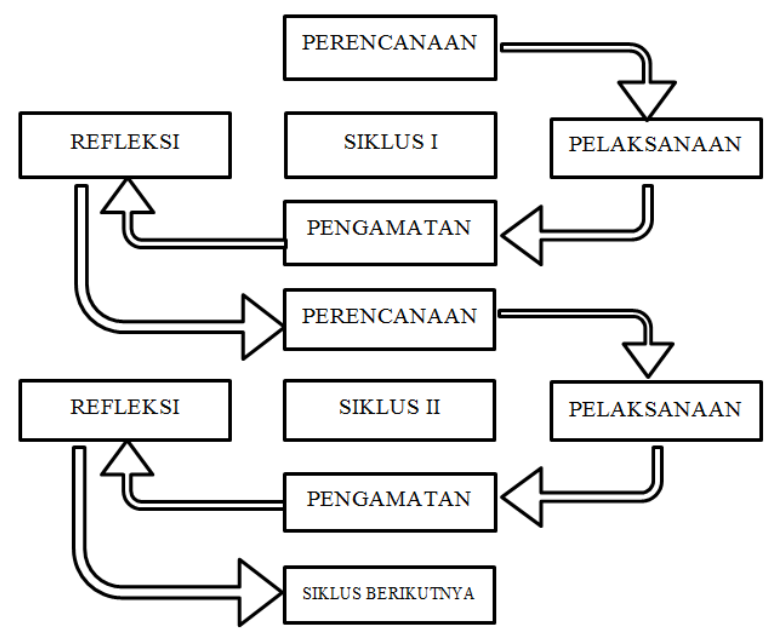

Gambar 1. Model PTK Suharsimi Arikunto

Berdasarkan rencana pelaksanaan pembelajaran sebelumnya dapat disusun perencanaan tidakan berikut ini:

a. Perencanaan Tindakan

Menyusun perangkat pembelajaran yang akan dilaksanakan yang meliputi komponen sebagai berikut:

1. Membuat Rencana Pelaksanaan Pembelajaran (RPP) pada siklus I dengan dengan menggunakan model pembelajaran talking stick.

2. Materi pembelajaran pada siklus I ini adalah kebutuhan hidup manusia dan kegiatan ekonomi.

3. Media/alat/sumber belajar, media yang digunakan adalah media video dan satu buah tongkat. Buku sumber seperti pada RPP.

4. Menyusun lembar observasi aktivitas guru dan siswa

5. Menyusun soal tes.

b. Pelaksanaan Tindakan

Pelaksanaan pembelajarab siklus 1 dilaksanakan pada rabu, 13 Maret 2019.

1. Mengkondisikan ruang belajar bagi siswa.

2. Peneliti melaksanakan pembelajaran sesuai dengan skenario pembelajaran dalam RPP siklus I.

3. Melaksanakan penilaian atau tes siklus I

c. Observasi

Observer melakukan observasi aktivitas guru dan aktivitas siswa pada saat proses pembelajaran

d. Refleksi

Merefleksi hasil evaluasi analisis data penelitian siklus I yaitu penilaian kualitas proses pembelajaran di kelas dan hasil evaluasi serta hasil diskusi dengan guru kelas dilanjutkan pada siklus 2 dengan perbaikan RPP.

\section{Siklus II}

a. Perencanaan Tindakan

Menyusun perangkat pembelajaran yang akan dilaksanakan yang meliputi komponen sebagai berikut:

1. Rencana Pelaksanaan Pembelajaran (RPP) pada siklus II dengan menggunakan model pembelajaran talking stick.

2. Materi pembelajaran pada siklus 2 ini adalah bentuk-bentuk kegiatan ekonomi.

3. Media/alat/sumber belajar, media yang digunakan adalah media gambar dan dua buah tongkat. Buku sumber seperti pada RPP.

4. Menyusun lembar observasi aktivitas guru dan siswa. 
5. Menyusun soal tes.

b. Pelaksanaan Tindakan

Pelaksanaan pembelajarab siklus 1 dilaksanakan pada jum'at, 22 Maret 2019.

1. Mengkondisikan secara lebih ruang belajar bagi siswa agar kondusif dari pembelajaran siklus I.

2. Peneliti melaksanakan pembelajaran sesuai dengan skenario pembelajaran dalam RPP siklus II.

3. Melaksanakan penilaian atau tes siklus II.

c. Observasi

Observer melakukan observasi aktivitas guru dan aktivitas siswa pada saat proses pembelajaran.

d. Refleksi

Merefleksi hasil evaluasi analisis data penelitian siklus II yaitu penilaian kualitas proses pembelajaran di kelas dan analisis hasil evaluasi serta diskusi dengan guru kelas yang kemudian dapat dilanjutkan pada siklus III dengan perbaikan RPP.

\section{Siklus III}

a. Perencanaan Tindakan

1. Rencana Pelaksanaan Pembelajaran (RPP) pada siklus 2 dengan menggunakan model pembelajaran talking stick.

2. Materi pembelajaran pada siklus 2 ini adalah jenis-jenis pekerjaan yang menghasilkan barang dan jasa.

3. Media/alat/sumber belajar, media yang digunakan adalah media gambar dan dua buah tongkat. Buku sumber seperti pada RPP.

4. Menyusun lembar observasi aktivitas guru dan siswa.

5. Menyusun soal tes.

b. Pelaksanaan Tindakan

Pelaksanaan pembelajarab siklus 1 dilaksanakan pada jum'at, 29 Maret 2019.

1. Mengkondisikan secara maksimal ruang belajar bagi siswa agar lebih kondusif dari pembelajaran siklus II.

2. Peneliti melaksanakan pembelajaran sesuai dengan skenario pembelajaran dalam RPP siklus III.

3. Melaksanakan penilaian atau tes siklus III.

c. Observasi

Observer melakukan observasi aktivitas guru dan aktivitas siswa pada saat proses pembelajaran.

d. Refleksi

Setelah melakukan analisis data, kemudian dievaluasi dan didiskusikan dengan guru kelas, dimana refleksi siklus 3 ternyata menunjukkan hasil yang baik.

\section{Hasil}

\section{Siklus I}

Berdasarkan hasil pengamatan diketahui bahwa permasalahan yang terjadi yaitu rendahnya hasil belajar siswa kelas IV pada mata pelajaran IPS. Setelah dilakukannya tindakan terjadi peningkatan setiap siklusnya.

Berikut ini adalah data hasil belajar siswa pada siklus I dapat dilihat pada tabel berikut:

Tabel 1. Hasil Belajar Siswa Pembelajaran Siklus I

\begin{tabular}{llcc}
\hline No & \multicolumn{1}{c}{ Kriteria } & Jumlah & Nilai rata-rata \\
\hline $\mathbf{1 .}$ & Belum Tuntas & 8 & 68,55 \\
$\mathbf{2 .}$ & Tuntas & 12 & \\
\hline
\end{tabular}

Berdasarkan tabel diatas, dapat diketahui bahwa pada pembelajaran siklus I, dari 20 siswa terdapat 8 siswa yang belum mencapai ketuntasan dan 12 siswa yang sudah tuntas, dengan hasil rata-rata 68,55 . Karena hasil belajar siswa pada 
siklus I, masih ada beberapa siswa yang belum mencapai ketuntasan belajar, sehingga perlu adanya penelitian tindakan kelas siklus II untuk melakukan perbaikan.

Diperoleh data saat pengamatan pada poses pembelajaran aktivitas guru dan siswa yang di amati oleh observer. Berikut ini data observasi aktivitas guru dan siswa selama proses pembelajaran sebagai berikut.

Tabel 2. Lembar Observasi Aktivitas Guru pada Siklus I

\begin{tabular}{ccc}
\hline Siklus & Persentase & Kriteria \\
\hline I & $63,46 \%$ & Baik \\
\hline
\end{tabular}

Kriteria:

$$
\begin{array}{ll}
0 \%-25 \%=\text { kurang baik } & 51 \%-75 \%=\text { baik } \\
26 \%-50 \% \text { = cukup baik } & 76 \%-100 \%=\text { sangat baik }
\end{array}
$$

Berdasarkan data yang diperoleh hasil pengamatan yang dilakukan oleh observer dalam aktivitas guru selama proses pembelajaran berlangsung yaitu $63,46 \%$ dengan kriteria baik. Komentar observer pun cukup baik, namun perlu direncanakan dan ditingkatkan lagi dalam proses pembelajaran. Untuk memperbaiki aktivitas guru selama pembelajaran yang belum maksimal dalam proses pembelajaran IPS maka perlu adanya perbaikan dan akan akan dilanjutkan pada siklus 2 .

Tabel 3. Lembar Observasi Aktivitas pada Siklus I

\begin{tabular}{ccc}
\hline Siklus & Persentase & Kriteria \\
\hline I & $60 \%$ & Baik \\
\hline
\end{tabular}

\section{Kriteria}

$$
\begin{array}{ll}
0 \%-25 \%=\text { kurang baik } & 51 \%-75 \%=\text { baik } \\
26 \%-50 \%=\text { cukup baik } & 76 \%-100 \%=\text { sangat baik }
\end{array}
$$

Berdasarkan data yang diperoleh hasil pengamatan yang dilakukan oleh observer dalam aktivitas siswa selama prose pembelajaran berlangsung yaitu $60 \%$ dengan kriteria baik. Komentar observer cukup baik, namun masih ada beberapa siswa yang kurang memperhatikan guru saat menjelaskan materi, masih ada siswa yang tidak tertib selama pembelajaran dan masih malu untuk bertanya dan menjawab pertanyaan. Untuk memperbaiki aktivitas siswa yang belum maksimal dalam proses pembekajaran IPS maka perlu adanya perbaikan dan akan dilanjut pada siklus II.

\section{Siklus II}

Data hasil belajar siswa dan aktivitas guru serta siswa selama proses pembelajaran pada siklus II dapat dilihat pada tabel di bawah ini.

Tabel 4. Hasil Belajar Siswa Pembelajaran Siklus II

\begin{tabular}{clcc}
\hline No & \multicolumn{1}{c}{ Kriteria } & Jumlah & Nilai rata-rata \\
\hline 1 & Belum Tuntas & 4 & 73 \\
2 & Tuntas & 16 & \\
\hline
\end{tabular}

Berdasarkan tabel di atas, dapat diketahui bahwa rata-rata hasil belajar siswa mata pelajaran IPS yang diperoleh dengan hasil 73 pada pembelajaran siklus 2 dari 20 siswa terdapat 4 siswa yang belum mencapai ketuntasan dan 16 siswa yang sudah tuntas. Ini menunjukkan adanya peningkatan hasil belajar dari siklus 1 ke siklus 2 yaitu 68,55 menjadi 73. Tetapi, karena masih ada beberapa siswa yang belum mencapai ketuntasan belajar, dengan demikian maka perlu adanya perbaikan proses pembelajaran pada siklus III. 
Tabel 5. Lembar Observasi Aktivitas pada Siklus II

\begin{tabular}{ccc}
\hline Siklus & Persentase & Kriteria \\
\hline II & $73,07 \%$ & Baik \\
\hline
\end{tabular}

Berdasarkan data yang diperoleh hasil pengamatan yang dilakukan oleh observer dalam aktivitas guru selama proses pembelajaran berlangsung yaitu 73,07\% dengan kriteria baik. Komentar observer pun cukup baik, namun perlu direncanakan dan ditingkatkan lagi dalam proses pembelajaran. Untuk memperbaiki aktivitas guru belum maksimal pada siklus II maka perlu adanya perbaikan pada siklus III.

Tabel 6. Lembar Observasi Aktivitas Siswa pada Siklus II

\begin{tabular}{ccc}
\hline Siklus & Persentase & Kriteria \\
\hline II & $70 \%$ & Baik \\
\hline
\end{tabular}

Berdasarkan data yang diperoleh hasil pengamatan yang dilakukan oleh observer dalam aktivitas siswa selama prose pembelajaran berlangsung yaitu 70\% dengan kriteria baik. Komentar observer cukup baik, namun masih ada beberapa siswa yang kurang percaya diri dalam mengajukan pertanyaan dan menjawab pertanyaan dari guru. Untuk memperbaiki aktivitas siswa yang belum maksimal maka perlu adanya perbaikan dan akan dilanjut pada siklus III.

\section{Siklus III}

Kegiatan pembelajaran pada siklus 2 sudah dilaksanakan, namun masih terdapat kekurangan dalam proses pembelajaran sehingga melanjutkan tindakan pada siklus III. Dalam kegiatan siklus III ini bertujuan memperbaiki kekurangankekurangan pada siklus 2. Berikut data hasil belajar siswa dan aktivitas guru serta siswa selama proses pembelajaran pada siklus III dapat dilihat pada tabel di bawah ini:

Tabel 7. Hasil Belajar Siswa Pembelajaran Siklus III

\begin{tabular}{clcc}
\hline No & \multicolumn{1}{c}{ Kriteria } & Jumlah & Nilai rata-rata \\
\hline $\mathbf{1}$ & Belum Tuntas & 0 & 85,4 \\
$\mathbf{2}$ & Tuntas & 20 & \\
\hline
\end{tabular}

Selama pelaksanaan tindakan pada siklus III, peneliti mampu memperbaiki kekurangan-kekurangan pada siklus I dan II. Proses pembelajaran pada siklus III ini menunjukkan peningkatan hasil belajar siswa yang terus meningkat. Pada pembelajaran siklus III, dari 20 siswa terdapat 0 siswa yang belum berhasil mencapai ketuntasan dan 20 siswa yang sudah tuntas, dengan nilai rata-rata 85,4. Ini menunjukkan adanya peningkatan hasil belajar 68,55 pada siklus I menjadi 73 pada siklus II dan 85,4 pada siklus III. Dengan demikian seluruh siswa mencapai Kriteria Ketuntasan Minimal (KKM) yang telah ditetapkan.

Tabel 8. Lembar Observasi Aktivitas Guru pada Siklus III

\begin{tabular}{ccc}
\hline Siklus & Persentase & Kriteria \\
\hline III & $82,69 \%$ & Sangat Baik \\
\hline
\end{tabular}

Berdasarkan data yang diperoleh hasil pengamatan yang dilakukan oleh observer dalam aktivitas guru selama proses pembelajaran berlangsung yaitu $82,69 \%$ dengan kriteria sangat baik. Komentar observer pun sudah baik, guru sudah jelas dalam menyampaikan materi dan dapat menguasai kelas dengan baik. Hal ini dapat disimpulkan bahwa dengan menggunakan model pembelajaran talking stick pembelajaran dapat meningkat. Karena adanya peningkatan dari siklus I 63,46\% menjadi $73,07 \%$ pada siklus II dan $82,69 \%$ pada siklus III. 
Tabel 9. Lembar Observasi Aktivitas pada Siklus III

\begin{tabular}{ccc}
\hline Siklus & Persentase & Kriteria \\
\hline III & $82,5 \%$ & Sangat Baik \\
\hline
\end{tabular}

Berdasarkan data yang diperoleh hasil pengamatan yang dilakukan oleh observer dalam aktivitas siswa selama proses pembelajaran berlangsung yaitu 82,5\% dengan kriteria sangatbaik. Komentar observer pun sudah baik, Siswa memperhatikan penjelasan dari guru dan aktif dalam mengajukan pertanyaan serta berani menjawab pertanyaan dari guru. Hal ini dapat disimpulkan bahwa dengan menggunakan model pembelajaran talking stick kegiatan belajar mengajar meningkat. Karena adanya peningkatan dari siklus I $60 \%$ menjadi $70 \%$ pada siklus II dan $82,5 \%$ pada siklus III.

Berdasarkan hasil data sikus I, II dan III yang telah di paparkan, maka itu dapat dibandingkan hasil data setiap siklusnya dengan diagram sebagai berikut.

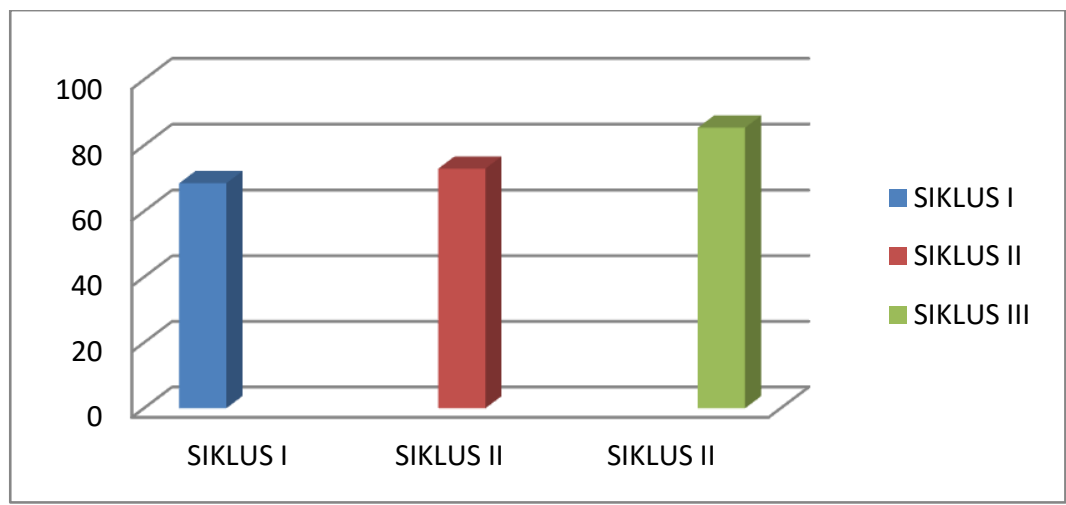

Diagram 1. Hasil Belajar Siswa pada Siklus I, II dan III

Berdasarkan diagram tersebut, dapat disimpulkan bahwa adanya peningkatan nilai rata-rata hasil belajar IPS menggunakan model pembelajaran talking stick. Pada siklus I yaitu 68,55 pada siklus II yaitu 73 , dan pada siklus III yaitu 85,4.

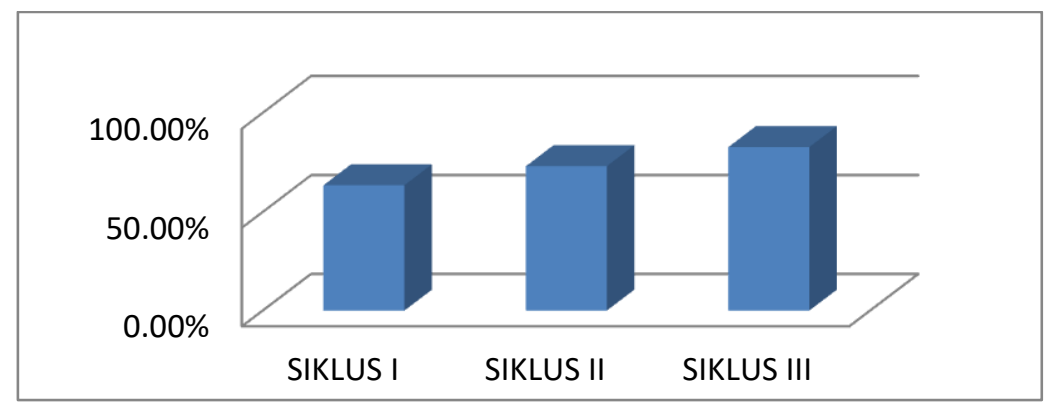

Diagram 2. Aktivitas guru selama proses pembelajarann pada siklus I, II dan III

Berdasarkan diagram di atas, dapat disimpulkan bahwa aktivitas guru selama proses pembelajaran menggunkan model pembelajaran talking stick mengalami peningkatan persentase setiap siklusnya, pada siklus I dengan persentase $63,46 \%$ dengan kriteria baik, pada siklus II dengan persentase $73,07 \%$ dengan kriteia baik dan pada siklus III dengan persentase $82,69 \%$ termasuk kriteria sangat baik. 


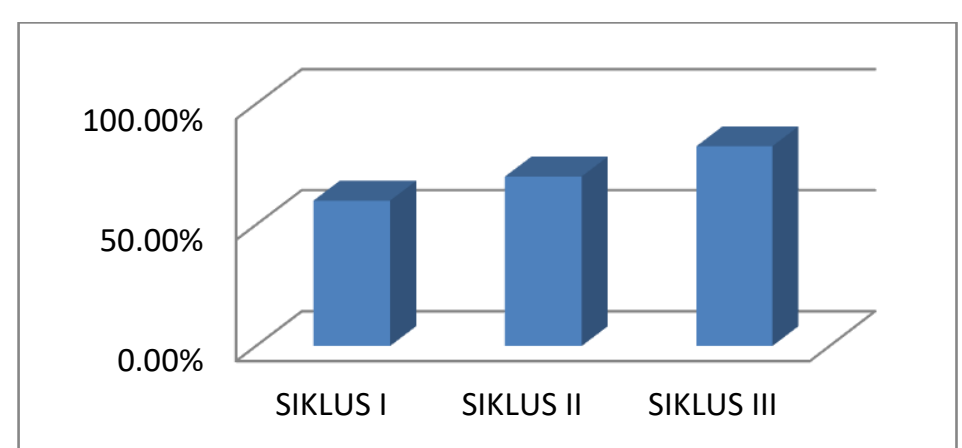

Diagram 3. Aktivitas siswa selama proses pembelajaran pada siklus I, II dan III

Berdasarkan tabel di atas, dapat disimpulkan bahwa aktivitas siswa selama proses pembelajaran menggunkan model pembelajaran talking stick mengalami peningkatan persentase setiap siklusnya, pada siklus I dengan persentase $60 \%$ dengan kriteria baik, pada siklus II dengan persentase $70 \%$ dengan kriteia baik dan pada siklus III dengan persentase $82,5 \%$ termasuk kriteria sangat baik.

\section{Pembahasan}

Berdasarkan hasil pengamatan, diketahui banyak siswa yang jenuh dan tidak konsentrasi ketika pembelajaran berlangsung, serta mata pelajaran IPS masih disampaikan dengan metode konvensional yang lebih dominan diterapkan dari pada metode yang lain, akibatnya respon siswa terhadap mata pelajaran kurang tertarik. Kemudian diperoleh data rendahnya hasil belajar siswa mata pelajaran IPS saat UAS (Ujian Akhir Semester) Semester 1 yaitu dengan hasil ujian dari jumlah 20 siswa hanya 10 siswa yang memperoleh hasil belajar yang mencapai KKM, dan 10 siswa memperoleh hasil belajar rendah dibawah KKM.

Dalam menyelesaikan rendahnya hasil belajar, dengan mendesain kegiatan pembelajaran yang optimal diperlukan kecermatan dalam memilih dan menerapkan model pembelajaran. Salah satunya dengan menerapkan model pembelajaran talking stick, sejalan dengan pendapat Suprijono (dalam Irma Novinda: 2016) mengungkapkan bahwa model talking stick mendorong peserta didik berani mengemukakan pendapat. Pembelajaran yang diawali penjelasan guru mengenai materi. Peserta didik diberi kesempatan membaca, mempelajari materi. Guru memberikan waktu cukup. Selanjutnya meminta peserta didik menutup bukunya. Guru menyiapkan tongkat dan tongkat diberikan kepada salah satu peserta didik. Peserta didik yang menerima tongkat tersebut wajib menjawab pertanyaan guru demikian seterusnya. 
Kemudian dilaksanakan tindakan secara keseluruhan, berdasarkan hasil pengamatan dengan guru wali kelas IV, pada waktu proses pembelajaran siklus I, masih ada beberapa siswa yang kurang memperhatikan guru saat menjelaskan materi karena masih kurang tertariknya siswa pada mata pelajaran IPS dan masih ada siswa yang tidak tertib selama pembelajaran serta masih malu untuk bertanya dan menjawab pertanyaan. Untuk memperbaiki proses pembelajaran yang belum maksimal maka perlu adanya perbaikan pada siklus II dengan meningkatkan model pembelajaran talking stick yang bervariatif, memberikan penguatan kepada siswa yang berani bertanya serta menjawab pertanyaan dan memperhatikan siswa secara menyeluruh.

Pada siklus II ditemukan masih ada kekurangan yaitu beberapa siswa yang malu bertanya dan menjawab pertanyaan, untuk memperbaiki kekurangan maka perlu adanya tindakan siklus III dengan mengoptimalkan proses pembelajaran dari awal hingga akhir dan memberikan penguatan berupa hadiah.

Pada siklus III terdapat hasil yang meningkat yaitu peserta didik saat proses pembelajaran tertib dan aktif . Memiliki antusias untuk bertanya dan berani menajawab pertanyaan dengan percya diri. Serta terciptanya suasana belajar yang menyenangkan sehingga mempengaruhi rasa giat peserta didik dalam belajar. Keberhasilan pembelajaran dengan menerapkan model pembelajaran talking stick ini juga terlihat dari hasil belajar siswa.

Peningkatan yang terjadi setiap siklusnya, siklus I nilai rata-rata siswa 68,55 dari 20 siswa, hanya 12 siswa yang tuntas dan 8 siswa belum tuntas. Siklus II nilai ratarata 73 terdapat 16 siswa yang tuntas dan 4 siswa belum tuntas. Dan siklus III nilai rata-rata menjadi 85,4 semua siswa telah mencapai ketuntasan.

Hasil observasi aktivitas guru dan siswa selama proses pembelajaran sama halnya mengalami peningkatan setiap siklusnya. Aktivitas guru pada siklus I dengan persentase $63,46 \%$, aktivitas siswa yaitu $60 \%$. Pada siklus II, aktivitas guru dengan persentase $73,07 \%$ dan aktivitas siswa dengan persentase $70 \%$. Kemudian pada siklus III, aktivitas guru menjadi $82,69 \%$ serta aktivitas siswa yaitu dengan persentase $82,5 \%$. Berdasarkan pembahasan tersebut, penelitian tindakan kelas yang dilaksanakan di kelas IV menggunakan model pembelajaran talking stick pada siklus I, siklus II, dan siklus III mengalami peningkatan di setiap siklusnya, baik dari aktivitas guru, aktivitas siswa maupun hasil belajar siswa.

\section{Kesimpulan}

Berdasarkan hasil penelitian yang telah dilaksanakan selama 3 siklus, terkait tentang meningkatkan hasil belajar IPS pada siswa kelas IV MI Nurul Huda 1 Curug Bogor Tahun Ajaran 2018/2019 dengan menggunakn model pembelajaran talking stick dapat disimpulkan dengan dilihat dari nilai rata-rata hasil belajar siswa yang selalu meningkat disetiap siklusnya diantaranya dapat dibuktikan dengan sebelum menggunakan model pembelajaran talking stick memperoleh nilai rata-rata 57,3. Setalah melakukan penelitian dari siklus I, siklus II dan siklus III membuktikan adanya peningkatan siklus I nilai rata-rata yaitu 68,55 dengan siswa yang tuntas 12 siswa dan belum tuntas 8 siswa, siklus II nilai rata-rata yaitu 73 dengan siswa yang tuntas 16 siswa dan belum tuntas 4 siswa dan siklus III nilai rata-rata yaitu menjadi 85,4 dengan siswa yang tuntas 20 siswa dan belum tuntas 0 siswa. Dan data yang diperoleh dari hasil pengamatan yang dilakukan oleh observer dalam aktivitas guru selama pembelajaran mengalami peningkatan dari siklus I dengan persentase $63,46 \%$, pada siklus II dengan persentase $73,07 \%$ dan pada siklus 
III dengan persentase $82,69 \%$. Sama halnya dengan aktivitas siswa selama pembelajaran mengalami peningkatan dari siklus I dengan persentase $60 \%$, pada siklus II dengan persentase $70 \%$ dan pada siklus III dengan persentase $82,5 \%$.

\section{Saran}

Ada beberapa saran yang dapat disampaikan pada penelitian ini adalah sebagai berikut:

1. Guru diharapakan tidak menerapkan metode konvensional dalam pembelajaran IPS, namun menerepakan model pembelajaran talking stick pada kegiatan pembelajaran dikelas,agar menubuhkan susana belajar yang menyangkan dan menumbuhkan semangat belajar siswa serta menumbuhkan sikap berani dalam mengemukakan pendapat sehingga meningkatkan hasil belajar siswa.

2. Penelitian ini diharapkan menjadi referensi bagi para pendidik agar dapat menggunakan model pembelajaran yang tepat dalam melaksanakan kegiatan pembelajaran.

\section{Referensi}

Arikunto, S. dkk. (2012). Penelitian Tindakan Kelas. Jakarta: PT Bumi Aksara.

Aqib, Z. (2016). Model-Model, Media, dan Strategi Pembelajaran Kontekstual (Inovatif). Bandung: YRAMA WIDYA.

Husnah, N. dkk. (2016). Penerapan Model Pembelajaran Kooperatif tipe Talking Stick untuk Meningkatkan Hasil Belajar Siswa kelas IV di SD Negri 017 Ranah Singkuang. Riau: Jurnal Online Mahasiswa Fakultas Keguruan dan Ilmu Pendidikan. Volume 3 No. 2 Tahun 2016 (1-12)

Iman Pambudi, R. L. (2017). Penerapan Model Pembelajaran Talking Stick Untuk Meningkatkan Hasil Belajar Matematika Pada Siswa Kelas IV SD Negeri Suryodiningratan II Tahun Ajaran 2015/2016. Yogyakarta: Jurnal Pendidikan Guru Sekolah Dasar. Volume 6 No. 1 Tahun 2017 (71-80)

Kurniasih, I. \& Sani, B. (2016). Ragam Pengembangan Model Pembelajaran Untuk Peningkatan Profesionalitas Guru. Jakarta: Kata Pena.

Mulyasa, H. E. (2012). Praktik Penelitia Tindakan Kelas. Bandung: PT Remaja Rosdakarya.

Novida, I. (2016). Penerapan Model Talking Stick untuk Meningkatkan Hasil Belajar IPS Pada Materi Jasa dan Peranan Tokoh Pejuang dalam Memproklamasikan Kemerdekaan Indonesia pada siswa Kelas V SD Negri 20 Meulaboh Kabupaten Aceh Barat. Aceh: Jurna Bina Gogik. Volume 3 No. 1 Tahun 2016 (1-14)

Shoimin, A. (2014). 68 Model Pembelajaran Inovatif dalam Kurikulum 2013. Yogyatakarta: AR-RUZZ MEDIA

Susanto, A. 2014. Teori Belajar \& Pembelajaran di Sekolah Dasar. Jakarta: Kencana Prenadamedia Group.

Sudijono, A. (2017). Pengantar Statistik Pendidikan. Jakarta: PT Raja Grafindo Persada. 
Harahap, H., N. Priatna, O., S. \& Nawawi, K.

Suyadi. (2015). Panduan Penelitian Tindakan Kelas. Jogjakarta: DIVA Press.

Syah, M. 2014. Psikologi Pendidikan. Bandung: PT Remaja Rosdakarya Offset.

Tampubolon, S. (2014). Penelitian Tindakan Kelas. Bogor: Erlangga.

Trianto. (2013). Model Pembelajaran Terpadu. Jakarta: PT Bumi Aksara. 